\title{
Reese-Ellsworth Classification VA
}

National Cancer Institute

\section{Source}

National Cancer Institute. Reese-Ellsworth Classification VA. NCI Thesaurus. Code

C123376.

Massive tumors involving more than one-half of the retina. 